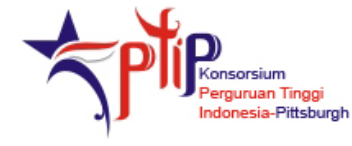

\title{
Developing and Using Open Education Resources to Support Teacher Education in Africa
}

\author{
Christopher B. Mugimu, ${ }^{\mathrm{a},}$ \\ ${ }^{\mathrm{a}}$ School of Education, Makerere University, Uganda
}

\begin{abstract}
This article presents findings of action research during the creation and dissemination process of open education resources (OERs) to support preservice and in-service teachers in Uganda and other African countries. It highlights the perceptions of teachers and the authoring team of the impact of their involvement in materials creation and dissemination on their practice and professional growth. It also presents lessons learned during the development and implementation process and the best practices for replicating this outreach program in Uganda and beyond. This article also shares insights into how the OERs can boost or contribute to effective teaching and learning especially in under-resourced school situations in Africa, and also shares experiences on best practices on creating the authoring team of OERs.
\end{abstract}

\begin{abstract}
Abstrak
Artikel ini membahas penelitian tindakan (action research) mengenai proses pembuatan dan diseminasi sarana pendidikan terbuka atau OER dalam rangka membantu para guru dan calon guru di Uganda dan negara-negara Afrika lainnya. Penelitian ini menyoroti persepsi guru dan tim kreator tentang pengaruh keterlibatan di proyek OER terhadap praktek dan pengembangan profesi mereka. Hasil penelitian juga menguraikan praktek-praktek unggulan dan hal-hal yang dipelajari selama proses pengembangan dan implementasi, sebagai upaya mereplikasi proyek ini di dalam dan di luar Uganda. Peneliti kemudian mengulas kontribusi OER untuk pengajaran dan pembelajaran yang efektif, terutama pada konteks sekolah di Afrika yang fasilitasnya masih kurang, sekaligus memaparkan beberapa praktek yang bisa diteladani dalam proses pembentukan tim kreator OER.
\end{abstract}

Key Words: Teacher Training, OERs, Professional Development, Action Research, ELATE Programme

\section{Introduction and Context of Education in Uganda}

Following the 1990 Jomtien worldwide education conference (UNESCO 1994), Uganda demonstrated commitment by introducing universal primary education (UPE) in 1997. Following the inauguration of UPE in 1997, pupils' enrollment in all UPE schools shot up from 3.4 million to over 5.4 million, and then to over 7.0 million by 2002 (Murphy 2003). The government of Uganda's commitment to providing free education to four children per family at the primary subsector level helped contribute to this sharp rise in students' enrollment. There was

*Corresponding author. Address: Department of Curriculum, Teaching and Media, School of Education, Makerere University, P.O. Box 4753, Kampala, Uganda.

Email: byalusagomugimu@gmail.com. great success in terms of seeing more children attending primary schools irrespective of the challenges arising from the inadequate infrastructure, shortage of well-trained teachers, and paucity of instructional materials. These challenges have tended to compromise the overall quality of education being offered especially by UPE schools. This is reflected in the high dropout rates after the primary education cycle. A substantially smaller number of students who graduate from their primary level schooling continue on for secondary education. Some argue this is a relative waste of limited financial resources in terms of the government's investment in UPE. For example, in the year 2000 of all the secondary school eligible age cohort only 13 percent registered/enrolled for secondary education. Secondary education is still highly skewed towards the higher income groups especially those coming from urban families (Ministry of Education and Sports [MOES] 2005). 
However, after registering some success - particularly in terms of students' enrollment in the now 13-year-old UPE project as reflected in Table 1 below-it seemed logical to introduce universal secondary education (USE) in Uganda. Government policy makers and planners hoped that by introducing USE enrollments would increase and there would be a minimized gender and rural-urban divide at the secondary subsector school level. Already in 2007, as reflected in Table 2, Uganda witnessed an influx of over-flowing numbers of students in enrolling USE schools thus exerting pressure on the system in terms of school infrastructure (classroom space, offices, and teacher housing), trained teachers, and limited financial resources (MOES 2008).

Table 1. Primary School Enrollment in Uganda (2000-2009)

\begin{tabular}{crrrrrrrrrr}
\hline Year & 2000 & 2001 & 2002 & 2003 & 2004 & 2005 & 2006 & 2007 & 2008 & 2009 \\
\hline $\begin{array}{l}\text { Enrollment } \\
\text { (millions) }\end{array}$ & 6.6 & 6.9 & 7.4 & 7.6 & 7.4 & 7.2 & 7.2 & 7.5 & 7.5 & 8.7 \\
\hline Source: & & & & & & &
\end{tabular}

Source: Republic of Uganda (2010) and Uganda Bureau of Statistics (2010).

Nevertheless, nearly two decades ago key stakeholders recognized the severe problem associated with school dropout particularly at the end of the Primary seven cycle. As is outlined in the Government White Paper on the Education Policy Commission Report (GOU 1992) - the Government of Uganda hoped there would be equal opportunities for all secondary school-aged youths (Kajubi 1992). This was based on the assumption that USE could expand educational access to create a more equitable social world. Therefore, it was apparent that the introduction of USE in Uganda created a pressing need to train many more teachers over a relatively short time period and to provide effective professional development opportunities to those teachers, already qualified, who sometimes had to teach subjects in which they had little or no training. Granted that secondary school teachers in Uganda are usually trained to teach two subject areas (e.g., History and Geography) because of an overall shortage of teachers, such teachers may be required to teach other subjects (for instance Economics, Religious Education, Mathematics) in which they did not qualify. In most Ugandan schools teachers quite often serve as the only source of instruction, emphasizes how imperative it is to have better-trained teachers. It is within the context of the USE enrollment explosion

Table 2. Secondary School Enrollment in Uganda (2000-2009)

\begin{tabular}{|c|c|c|c|c|c|c|c|c|c|c|}
\hline Year & 2000 & 2001 & 2002 & 2003 & 2004 & 2005 & 2006 & 2007 & 2008 & 2009 \\
\hline $\begin{array}{l}\text { Enrollment } \\
\left({ }^{\circ} 000 \mathrm{~s}\right)\end{array}$ & 519 & 540 & 656 & 684 & 698 & 728 & 814 & 954 & 828 & - \\
\hline
\end{tabular}

in recent years that has formed the basis for the establishment of the E-learning and Teacher Education (ELATE) Programme.

\section{Overview of the ELATE Programme}

This article draws upon the experiences gained from the ELATE Programme, which was a collaborative teacher professional development initiative between Makerere University (Uganda) and the Open University (UK). ELATE engages in the development of open education resources (OERs) to support teachers and is disseminated via three primary mediums: online through its web portal; via CD-ROM distribution, especially in contexts where Internet access is limited or non-existent; and by hard-copy instruction materials. Since its establishment in 2007 ELATE has included parallel action-research centered on the following four objectives:

1. Raise the effectiveness of teacher training in Uganda by enabling trainers to enhance their capabilities through working together with other education stakeholders, including school and private sector employers.

2. Create OERs for trainees and practicing teachers in secondary schools to raise their effectiveness and employability while also helping to raise the proportion of qualified students graduating from secondary education and reducing "drop-outs."

3. Disseminate teacher guidance and learning materials that make the school classroom experience more active, engaging, and locally relevant.

4. Through active learning activities, (a) develop transferable and problem-solving skills relevant to the world of work, (b) develop the individual ability to use information communication technology (ICT) in real contexts, and (c) integrate entrepreneurial skills that are needed to enhance the employment prospects of school leavers.

The main focus of the ELATE Programme is to train teacher educators and trainees at Makerere University how to prepare and use OERs to enhance effective teaching and learning in underresourced secondary school settings. An essential part of this training process is preparing exemplary curricula materials along with classroom activities and teachers' guides. The program realized the enormous potential of the worldwide web and CDROMs to support preservice and professional teachers in secondary schools. 
Given the dearth of materials for new teachers in Uganda, ELATE administrators decided to make the OERs available in draft form. So, units were initially uploaded before they were fully developed because the project team knew that they could be modified and improved later in response to feedback from the users .The project team comprised of project directors, administration and management staff.

Across the globe there is increasing interest in different forms of school-based modes of teacher education and in using the tools offered by new ICTs, including OERs, for large-scale dissemination projects and needs (Moon, Leach, and Stevens 2005). These initiatives not only increase capacity for teacher training systems, but also offer opportunities to enhance the articulation between theory and practice and support teachers more effectively in becoming reflective practitioners.

Moon (2007) contends that school-based teacher development programs demand resources and reference materials to guide and grow teachers' classroom practices. These are frequently scarce in sub-Saharan African contexts. However, the recent advent of open content or OERs, a global intellectual resource of teaching materials, offers a significant breakthrough.

Furthermore, given the general perception that Africa is only a consumer of OERs, the ELATE Programme set out to break the mold by creating a center of expertise in the production of African-based OERs - developed by Africans for Africa. The project team went through a series of workshops in Uganda to refine its plans and reach a clear understanding on the methods of implementation. The project team recruited 42 highly-qualified writers of subject content for the preservice and in-service teacher training support.

Figure 1. Education Stakeholders Involved in the ELATE Programme

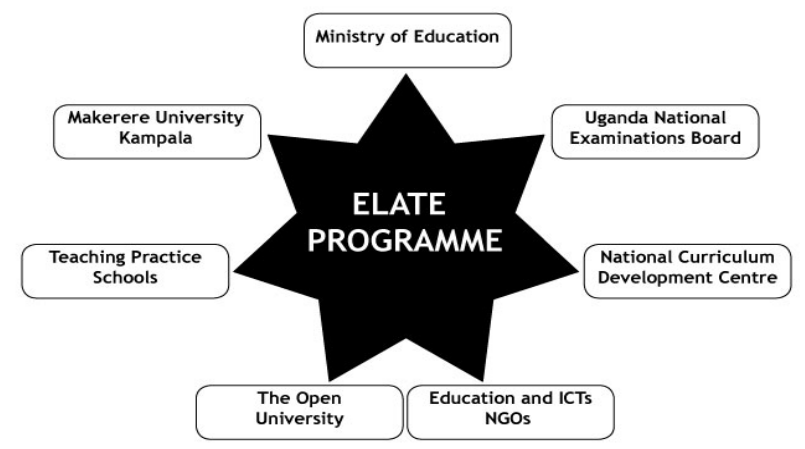

In the process of conducting the ELATE Programme there has been a growing realization that examination syllabi in Uganda are often too broad and academic for the majority of students coming into schools through USE. Therefore, the project team strategically involved key education policy, planning, and decision makers in Uganda as shown in Figure 1, including the National Curriculum Development Centre (NCDC), Uganda National Examinations Board (UNEB), and the Ministry of Education and Sports (MOES).

The project team also included other key stakeholders such as Makerere University, secondary schools on teaching practice, and education and ICT nongovernmental organizations. The project team felt that involving all these key stakeholders in the ELATE Programme from the beginning would contribute to the ongoing discussions of the national curriculum reform movement in Uganda. This is because the involvement of key stakeholders brought in the dimension of value congruence as advocated for by Harland and Kinder (1997). In this context, value congruence may refer to materials that teachers perceive as good practice and beneficial to their work. The overarching goal was to bring on board all key stakeholders so that they would see/perceive the value congruence of the program and its activities. Thus, all stakeholders shown in Figure 1 were involved during the initial stages of planning for the creation, dissemination, implementation, and evaluation of the OERs through multiple workshops and consultation meetings. The project team soon realized that cultivating goodwill and the spirit of working together among stakeholders in devising strategies of creating ecurriculum materials to support pre-service and in-service teachers was critical.

\section{Organization of the ELATE Programme}

ELATE was organized with the following management entities: Programme Management Team assisted by the Programme Advisory Board, Curriculum Authoring and Editing Teams, entrepreneurs who could offer enterprise advocacy, a Programme Administrator/Secretariat, and support staff including graphic designers and webmasters. The Project Management Team coordinated all program activities such as hired personnel, organized meetings and workshops, monitored the material development process, and often became involved in the editing of materials. The Programme Advisory Board provided support and guidance through numerous forums especially during the initial stages of the program. The curriculum authors and editors were mainly responsible for writing and editing materials. However, they also assisted in piloting these materials especially in their own assigned schools where they were employed as well as 
sharing them with their colleagues in other schools. The enterprise advocates worked with several schools to orientate teachers with the materials especially in showing them various possibilities on how to use them. The Programme Administrator and Secretariat as well as other support staff assisted in the data entry, development of the web pages, and creation of appropriate graphics. All these individuals were drawn from stakeholders shown in Figure 1.

\section{Choosing the Curriculum Authoring Team}

The Curriculum Authoring Team was comprised of experts from stakeholders listed in Figure 1. Many of these individuals had extensive experience in the development and implementation of the Uganda's national curriculum at all levels of education. NCDC not only develops the curriculum for all levels of education - starting from primary, secondary, post-secondary education, and tertiary education-but also disseminates the curriculum throughout the country. UNEB is responsible for the assessment and evaluation of the curriculum. In Uganda, national examinations tend to drive the formal curriculum. Interestingly, once schools achieve excellence in performance in public examinations, parents and their students struggle to gain admission into those best performing schools. As such the topperforming schools on public examinations tend to gain and enjoy more student enrollments than their counterpart schools. MOES oversees and monitors the implementation of the national curricula as well as dealing with the appointment and deployment of teachers in Uganda. Other stakeholders included on the Curriculum Team were teacher educators from the School of Education at Makerere University, practicing teachers from the best performing schools who have set themselves apart as subject experts and excellent performing teachers, and publishers. Teacher educators at the School of Education were part of the curriculum team so as to enable them to apply and incorporate the curriculum materials in their teaching programs and teaching practice as well.

Table 3. Date, Location, Dissemination Workshops and Number of Participants

\begin{tabular}{|c|c|c|c|}
\hline Date & Venue & Convener & Number of participants \\
\hline September 19, 2009 & Mbarara western region & $\begin{array}{l}\text { English language/elate teachers } \\
\text { workshop }\end{array}$ & $\begin{array}{l}248 \text { teachers from } 100 \text { secondary } \\
\text { schools }\end{array}$ \\
\hline March 3, 2010 & British Council-Kampala & $\begin{array}{l}\text { ELATE feedback presentation. } \\
\text { Participants were drawn from all BC } \\
\text { funded projects in Uganda }\end{array}$ & More than 40 people participated \\
\hline March 20, 2010 & Lira Town Council Northern region & $\begin{array}{l}\text { English language/elate teachers } \\
\text { workshop }\end{array}$ & $\begin{array}{l}264 \text { teachers from } 120 \text { secondary } \\
\text { schools }\end{array}$ \\
\hline March 27, 2010 & Jinja Eastern region & $\begin{array}{l}\text { English language/elate teachers } \\
\text { workshop }\end{array}$ & $\begin{array}{l}289 \text { teachers from } 150 \text { secondary } \\
\text { schools }\end{array}$ \\
\hline April 16-18, 2010 & $\begin{array}{l}\text { NCHE annual exhibition at Lugogo } \\
\text { Show ground Kampala }\end{array}$ & $\begin{array}{l}\text { University students, lecturers, policy } \\
\text { makers and government officials from } \\
\text { the central region }\end{array}$ & $\begin{array}{l}\text { This attracted participants from East } \\
\text { African public and private universities, } \\
\text { other tertiary institutions, policy makers } \\
\text { and government officials }\end{array}$ \\
\hline May 15, 2010 & $\begin{array}{l}\text { Makerere University School of } \\
\text { Education conference }\end{array}$ & University students of education & 250 teacher trainees \\
\hline June $10-12,2010$ & $\begin{array}{l}\text { Makerere University ELT National } \\
\text { Annual Conference held at the School } \\
\text { of Education }\end{array}$ & $\begin{array}{l}\text { English language/elate teachers } \\
\text { workshop }\end{array}$ & $\begin{array}{l}385 \text { teachers from } 250 \text { secondary } \\
\text { schools }\end{array}$ \\
\hline
\end{tabular}


Table 4. Summary of the ELATE Statistics of Evaluation and Dissemination Activities

Authors and Editors

Academic Staff at the School of Education

CD ROMs

Web Portal

Units of Materials

Brochures

Business Cards

Teacher Trainees

Teacher Trainers
Forty-two authors and eight editors were involved in the creation of materials, and currently more than 30 authors/teachers have reported to be using these materials for their teaching. The project team has received 35 evaluation responses back from authors and editors.

The eight academic staff/editors are utilizing the materials to train teacher trainees and also encourage their colleagues to use the materials. More than 20 staff members have also integrated these materials into their lectures. This is almost 25 percent of all School of Education staff. The project team randomly distributed forty evaluation forms to staff and only twenty-three have been returned. The comments are very positive.

To date more than 3,000 CD ROMs have been distributed to teacher trainees, practicing teachers, school administrators, NCDC, UNEB, and MoES. In May 2010, close to 400 CD ROMs were distributed to school practice partnering secondary schools around Uganda that took on teacher trainees from Makerere University. There is renewed interest of teachers in the revised latest CD ROM with current information. Practicing teachers have filled fifty evaluation forms and majority of them contain encouraging responses. It comes out clearly that teachers find the materials very useful and relevant to their work.

Between June 2009 and June 2010, the project team had over 240,000 hits on its website (www.ugandaschoolresources.org). This is a very promising start, as the project team continues to add more information in the future, many more people will be attracted to visit and use this website.

Nine units for each of the eight subjects covered have been created and uploaded to the website. In addition, a special topics section has been added, which comprises one unit on enterprises, with 20 case studies on entrepreneurs operating various businesses in Uganda, another unit is on oil in Uganda, and the last unit is on malaria has been added. This special topics section of the website is intended to offer general knowledge and promote transferable skills to the users.

Over 2,000 hours courseware materials have been made available to teachers via the web portal, $\mathrm{CD}$ ROMs, and in hard copy.

Over 6,000 brochures have been distributed to a broad range of clientele in different parts of Uganda as well as other countries, where the project team have travelled to attend conferences and workshops.

The project directors, administrators and enterprise advocates carry elate business cards and have used over 800 of them during the last year.

Over 6,000 teacher trainees have been oriented to materials: 3,500 trainees in 2008/2009 and 2,500 in 2009/2010 respectively. All second year teacher trainees take an educational technology curriculum course in which ELATE materials have been incorporated. As part of the assignment, teacher trainees are asked to create any unit of their choice and to give suggestion on how to improve these materials. Indeed, 250 evaluation forms returned by these trainees indicate that they found our materials very desirable during their school practice exercise.

Teacher trainers were given CD ROMs to take to schools where they had assigned some of their teacher trainees. Thirty evaluation forms returned by teacher trainers showing clearly that a good number of them actually utilize the materials during their lectures and are also encouraging their teacher trainees to use the same materials through assignments.
Practicing teachers in the field were expected to bring with them invaluable practical experience and expertise in various subject disciplines needed to develop appropriate curriculum materials. Practicing teachers were also offered opportunities for trying out or testing and using the curriculum materials being developed. Publishers were also included because the project team realized the need to publish the materials being developed. The project team also wanted to draw on the practical experiences they already had in creating instructional materials for publishing. The bottom line was that should there be any need for curriculum reform as a result of the curriculum materials developed through the program, given the nature of our Curriculum authoring and editing Team, it would be much easier to influence policy as needed. 


\section{Curriculum Content}

The ELATE Programme focuses mainly on enriching existing materials by adding more activities intended to enhance the development of transferable life skills. The activities include communication, numeracy skills development, and the ability to use generic-ICT in the context of real tasks. Nine units have been created and much more attention has been given to developing new materials that support the new compulsory Entrepreneurship curriculum introduced in 2009. Indeed, the concept of developing materials to enhance entrepreneurial skills has also been extended to all the eight core subjects: English language, History, Geography, Entrepreneurship, Biology, Physics, Chemistry, and Mathematics.

During the past year over 2,000 CD-ROMs have been disseminated to schools and over 1,000 CD ROMs distributed to practicing teachers during regional workshops in Uganda's Central, Eastern, Northern and The western Regions (see Table 3). The revised and updated curriculum materials have been uploaded on the web portal and are accessible for teachers and the public at the following URLs:

\section{www.ugandaschoolresources.org www.elateafrica.org}

Many teachers have found these curriculum materials useful and relevant to their work places. Already, large numbers of people are accessing these materials as reflected by the 240,000 hits registered on ELATE the project website during the past year (2009-2010). However, in the future it will be interesting to know where and which parts of the world these teachers and individuals using the materials come from. Nevertheless, it is reasonable to assume that the majority of our clients utilizing the materials most likely come from the East African Region given the increasing influx of student numbers studying in Uganda from neighboring countries like Kenya, Tanzania, Rwanda, Burundi, Sudan, and Democratic Republic of Congo.

Efforts have been made to disseminate ELATE curriculum materials and raise awareness of the stakeholders about the materials. Table 4 provides a summary for some of the evaluations and dissemination activities conducted within the past year. Taking the materials to potential users and orientating them to these materials is critical because even if these materials are good but are rarely or never used, their purpose becomes selfdefeating in terms of their contribution towards the enhancement of the quality of education. Indeed, a lot more work needs to be done to raise the awareness and knowledge of teachers and the general public in Uganda and other countries in Africa about these materials and how they can be accessed and used. Thus, the program evaluation study guide by following guiding research questions was necessary to explore the perceived impact of participants' interaction with materials.

\section{Guiding Research Questions}

This program evaluation study was guided by two primary research questions.

1. What are the perceptions of pre-service and in-service teachers of the influence of their interaction with the ELATE curriculum materials on their professional growth? This question was intended to gather information to assist the project team understand the benefits and usefulness of the elate curriculum materials from the actual users and beneficiaries. The gathered data users and informed the editing process of the existing and new materials. It was also important to learn directly from the curriculum authors and editors, hence led to the second research question.

2. What are the perceptions of the curriculum authoring and editing team members of the influence of their participation in the creation, dissemination, and implementation of ELATE curriculum materials on their professional growth? This question was intended to unveil the feeling of authors and editors about what they thought they had gained through their participation in all ELATE activities. It was also important to learn from them about what they throughout would be the best way to improve the materials and make them more relevant to the teachers.

The section that follows discusses the methods and procedures used to gather information to address the two guiding research questions stated above.

\section{Methodology}

Data sources included mainly evaluation forms and questionnaires. This section highlights the methods and data collection procedures undertaken in this study.

The project team designed several evaluation forms for the key stakeholders namely the curriculum authors and editors, teacher educators, teacher trainees, and practicing teachers. The evaluations questions included in the evaluation forms are reflected in Table 5. An ongoing informal evaluation of materials has been carried out in schools and Makerere University by the enterprise advocates. Because some of the authors and enterprise 
advocates the project were actually also teaching in secondary schools were given the opportunity to use the curriculum materials before they are finalized, this gave them the chance to identify errors and weaknesses that needed to be rectified. However, the project team has also developed a formal evaluation instrument, which is being used for peer group evaluation by preservice and novice teachers. Each of the 72 units has been independently evaluated by one trainee and one practicing teacher. The project team ensured that all the units were evaluated in time to begin a round of revisions and edited the work basing on the obtained valuable feedback. The project team also implemented a pilot program with preservice teachers and strategies for disseminating during school practice.

A set of evaluation and research instruments, in the form of questionnaires, has also been developed and tested. Each of these has been administered to teacher trainees, teacher educators, authors, editors, and practicing teachers. Initial analysis has been undertaken.

In this analysis, the project team used data gathered through the evaluation forms administered at different times within a period of two years to various stakeholders of the program. Those included in our sample were 40 authors, eight editors, 250 preservice teachers, 50 practicing teachers, 30 teacher educators, and four enterprise advocates. Careful attention was taken to ensure that those people from whom the data was collected had either participated in the creation and dissemination of the curriculum materials or had been oriented to as the curriculum authors, editors, and enterprise advocates used the materials in their teaching in a classroom situation.

Several teacher educators have incorporated the curriculum materials into their teacher training courses. Data was gathered from the following list of evaluation questions disseminated to all participating authors and editors:

1. To what extent has your involvement with ELATE materials affected your practice?

2. To what extent have you been actively involved in the dissemination of the materials?

3. To what extent are the elate materials contributing towards the support of novice teachers and practicing teachers?

4. What do you see as the major obstacles in utilizing the ELATE materials in schools?

5. What suggestions do you have to improve the ELATE materials?

6. What have you gained or learnt from using the ELATE materials?
7. How useful are the curriculum materials being created and disseminated?

8. In your view, what has the project management team done right?

9. How could the project management team improve?

This study was guided using a Grounded Theory approach, which helped generate concepts, themes, and subthemes that the project team generated (Strauss and Corbin 1998). This Grounded Theory approach informed our interpretation and understanding of what was going on, and what challenges the participants were going through and what they were doing to solve these challenges. In particular, Ground Theory helped us in appreciating the main concerns of the participants and to get a better understanding of what is going on. The generated concepts, themes, and subthemes were compared and aided in the conceptualization of the ELATE activities particularly the processes of material development, dissemination, and implementation. Twelve themes have been identified and are presented in the following results section.

\section{Results}

This section presents some of the salient findings from the ongoing evaluation study of the ELATE Programme. It provides highlights and insights on the perceptions of the concerned stakeholders involved in the development and use of the OERs (i.e., curriculum authors and editors, practicing teachers, teacher trainees, and enterprise advocates). Valuable insights arise from the voices of teachers and other stakeholders and what comes through clearly is that many of them testified of having gained substantial professional growth out of their involvement in the program.

\section{Mapping Professional Growth to Developing and Using OERs by Teachers in Africa}

Figure 2 shows the key stakeholders involved in the ELATE Programme and highlights the different workshops organized for the purposes of brainstorming and sharing ideas among the key players of the program. The creation of the ELATE curriculum materials has involved a large team comprising 42 authors (all experienced teachers), eight teacher trainers and educators responsible for subject training, who worked as editors, eight subject group coordinators (made up of Makerere University and secondary school teachers), two the project web-developers, a graphic designer; and secretarial support. This group of people has met together for numerous all-day Saturday workshops and there have been numerous ad hoc meetings of individual subject 
Figure 2. Professional Growth Gained through Workshops and Participation in Developing and Using OERs by Teachers in Africa

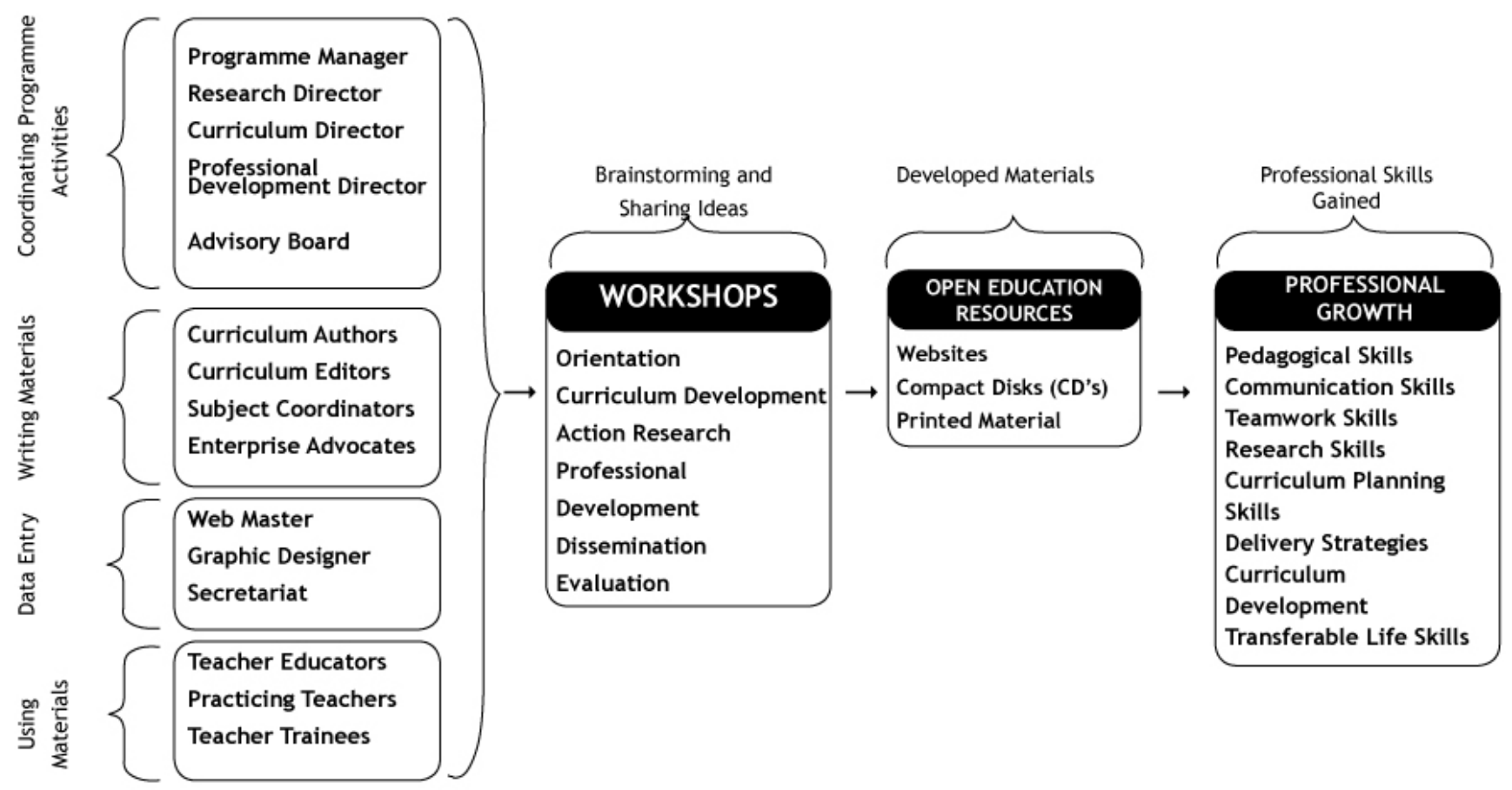

Source: Created by the author.

groups. All stakeholders reported having gained valuable experience and skills through workshops and their involvement with the ELATE Programme activities as reflected in Figure 2.

The analysis of data gathered from curriculum authors and editors on their perceptions of the impact of their participation in the creation and dissemination of curriculum materials on their professional growth and capacity building revealed important insights. Figure 2 indicates clearly that some of the stakeholders gained numerous professional skills through workshops and their involvement with the development and use of the OER curriculum materials. Some of the professional experience and skills gained by the stakeholders include: pedagogical skills, communication and writing skills, teamwork skills, research skills, curriculum planning and development skills, transferable life skills, and subject content delivery strategies. The curriculum authors and editors reported these considerable gains arising from having an opportunity to work and share ideas with other colleagues within and outside their subject areas. They also reported having acquired curriculum and e-materials development skills and are very positive about their involvement in the ELATE Programme.
The rest of this section presents the perceptions and responses of various stakeholders regarding the gained professional experiences and skills.

\section{Pedagogical Skills}

Several curriculum authors and editors acknowledged considerable professional gains in terms of pedagogical skills as a result of their involvement with the development of OERs and sharing ideas with peers during workshops. For instance, in response to the question-To what extent has your involvement with ELATE materials affected your practice? — several authors and editors reported that they had gained vital pedagogical skills:

The materials the project team has created have enhanced my pedagogical approach to English. I now teach better. My lessons are livelier, more meaningful, less of examinationoriented and more of skills-oriented, which is beneficial to my learners. (AU1) 
It has made me become a practical history teacher and given me a serious challenge to use the students in their own learning. (AU2)

I have widened my expression as regards handling of the subject as it has made me to be more creative and innovative in the ways of teaching. This is due to the practical knowledge acquired from ELATE that I was not exposed to from my previous training. (AU3)

Most of the authors and editors also reported having gained valuable presentation skills, which enhanced their confidence in teaching and ability to support students' learning processes. This is reflected the following quotation from one of the authors: "As a teacher ELATE has improved my way of presentation of the subject matter. It has refreshed my way of preparing schemes of work and writing lesson plans. More importantly it has helped me focus on contemporary learning in my subject" (AU4).

These teachers not only gained pedagogical skills but also research skills. Increasingly, teachers are challenged to become reflective practitioners (Freiberg and Driscoll 2005) as reflective practitioners and research skills are extremely vital (Good and Brophy 2003).

\section{Action Research Skills}

The ELATE Programme has created ongoing action research opportunities for the academic staff at the School of Education, Makerere University, the Open University, as well as other stakeholders involved (curriculum authors and editors, practicing teachers and enterprise advocates). Many of these authors and editors indicated their excitement about the numerous important research skills they had achieved through participation in the program. This is reflected in the following quotation:

It has taught me to research more in order to produce quality work in whatever I do. I have gained experience regarding curriculum designing, formulating feasible and measurable learning outcomes, and objectives. I have participated in monitoring and mentoring teachers and evaluation of these materials before they are uploaded on the website. (ED1)

Indeed, given that teacher trainees go for school practice each year, the evaluation of the curriculum materials and of trainee knowledge and attitudes towards the OERs will be conducted each year for several years to inform theory and practice. The longitudinal data set created will provide great opportunities for future research analysis and publications particularly for the faculty. This research experience would enhance teachers' decisions regarding their choices in selecting curriculum content and using appropriate instructional methods that are inline with the goals (Good and Brophy 2003).

As such, many indicated that their experience with the ELATE Programme helped them understand their subject content better for different classes they teach than before. One of the authors reported that: "I have become more knowledgeable about the subject content for different classes. In assessment, it is now much easier for me to set up any form of test or examination" (AU6).

\section{Communication and Writing Skills}

The program has improved the curriculum development and course writing skills of everyone concerned. This achievement is illustrated in the following author response:

It has improved my ability to develop relevant curriculum for learners. It has also strengthened my capacity in developing up-to-date teaching-learning materials such as Teachers Guides and Resource Books. (AU12)

One of the editors also indicated that he

had gained a great deal of insights from ELATE activities, they have opened up my approach to writing English books, linking teachers and learning materials has enabled me sort out concept-development and demonstration of appropriate methodology and technique issues. (ED5)

Furthermore, another author in his own words also reported on his interaction with the program activities:

It has transformed me into a consultant in the teaching of my subject. It has enabled me to move to several schools to talk to teachers about ELATE. It has transformed me into a better teacher. (AU15)

In addition, one of the editors testified in his own words on his involvement with the program activities: "It has enabled me to influence more teachers both where I work and teachers from other schools. It enables me to interpret theory and practical work" (ED7). An author also indicated that "It has improved my writing skills for the creation of my own instruction materials and designing activities in the various teaching disciplines/subjects" (AU27).

The communication and writing skills gained by the stakeholders assisted them to translate their action research 
findings into useful instructional materials and extended the possibilities for future publications and collaborations. In the process of indulging themselves in action research activities and sharing ideas, the stakeholders gained teamwork skills.

\section{Development of Teamwork Skills}

There has been sharing of good practice of sharing among members of the subject groups, and each group has also gained ideas from different subjects in the inter-disciplinary workshops. This is illustrated by the following response of an ELATE author: "It has greatly enabled me to learn new ideas and also share with my colleagues" (AU12). Another author also reported that "the spirit of team working and sharing of ideas has been enhanced" (AU16).

Over the initial three-year period of the program's existence, most of the curriculum authors, editors, teacher educators, and some of the practicing teachers have been bound together and have developed a community of reflective educators. There was much excitement in the workshops and during dissemination activities. Indeed, the stakeholders would agree that they have experienced considerable gains in teamwork skills.

\section{Curriculum Development Skills}

Everyone has learned to prepare electronic content and to structure materials in such a way that it is suitable for uploading onto the worldwide web, and have been made aware of the huge potential of e-delivery of materials to teacher trainees and practicing teachers. There has been a genuine buzz of excitement among the working groups, who are justly proud of the work they have completed. Teachers in schools partnering with Makerere University through teaching practice and university staff have acquired skills in creating innovative e-learning curriculum materials and dissemination of e-content. Many of these individuals have also become more creative and innovative in their teaching especially as regards incorporating transferable life skills usually enhanced through their classrooms activities.

\section{Transferable Life Skills}

Most of the key stakeholders perceived their interaction with the program activities and materials as being a form of transformational experience in terms of theory and practice. Many teachers have changed their teaching strategies as a result of using the ELATE materials as indicated in the following quotations:
Transferable life skills have become part and parcel of my lessons. I no longer wait to give these skills separately but I integrate them through out my lessons. The questions I set for my classes have at least some application of transferable life skills. (AU22)

It has changed my teaching approach to every topic a great deal; now I try to simplify everything even more than before, as well as to include the social and life skills in all subtopics. (AU26)

I have improved on my communication, interpersonal, and entrepreneurial skills. (AU18)

Transferable life skills have increasingly become more important in the global economy and the young people need them to become more competitive and productive. Indeed, many young people currently lack basic communication, interpersonal, numeracy, ICT literacy, and entrepreneurial skills. Most teachers may not have access to instructional materials that could enhance transferable life skills. However, the authors, editors, enterprise advocates, teacher educators, and practicing teachers have gained these important skills as well as instructional materials dissemination skills.

\section{Curriculum Dissemination Skills}

When authors and editors were asked the extent to which they participated in the dissemination of the ELATE materials, many of them indicated that they had been distributing and encouraging many of their colleagues to use these materials. They engaged in a wide range of dissemination efforts/activities such as distributing CDs to fellow teachers, installing the materials on staff computers and sharing information about ELATE materials by distributing brochures. For instance one of the editors reported that he has "installed OERs on staff computers to allow more teachers access the materials" (ED5). Another author also reported that "I have shared the ELATE materials with between 200 to 250 teachers, mainly through the CDs and brochures that I sent to five-linked secondary schools" (AU21).

\section{Support for Novice and Practicing Teachers}

In response to the question-To what extent are the elate materials contributing towards the support of novice and practicing teachers? - most of the authors and editors agreed that the materials supported novice and practicing teachers as exemplary resources for scheming and drawing lesson plans as 
well as using class activities that promote active learning. For instance, one author responded that

ELATE materials have been an eye opener even to us the authors as the materials have been very useful, especially for writing schemes of work and lesson plans for young teachers. The lesson plans and schemes of work help novice and practicing teachers to generate lesson plans and incorporate transferable life skills. Industrious teachers can generate similar work on different topics. These materials, provide a sound source of reference for their teaching, and give activities to teachers to engage learners. (AU9)

Therefore, the materials have helped many novice teachers develop a good foundation since planning is a very critical component of effective teaching. Given that "the decisions teachers make during planning strongly influence their classroom instruction" (Ornstein 1995, 119). These novice teachers go for teaching practice for the first time particularly in under-resourced schools without the needed materials to make their work easier. Thus, the notion that the ELATE materials could improve their school practice experiences is reflected in the following quotation:

The materials can be used by anybody anywhere and can be used for educational purposes. I have also been able to pass on the materials to teachers doing their school practice and they were happy to incorporate the materials in their lessons. The break-down of activities and their logical arrangement has been particularly helpful. (ED3)

Indeed, several teacher trainees also reported that their access to ELATE materials enriched their school practice experience. The sentiments of teacher trainees on how the materials made their lives easier during school practice are reflected in the following quotations:

I went for my school practice for the first time, but I found the materials very helpful because they provided well written lesson plans, schemes of work, and practical examples and activities. (Teacher of English)

I liked the life skills and entrepreneurial skills incorporated in my subject area. (Teacher of Biology)

The teacher guidance as well as illustrations provided were of great help. (Teacher of History)
When I used the ideas given in these materials, my students enjoyed my lessons better and their learning was evident. The exercises provided were so simplified. (Teacher of Mathematics)

The utilization of local examples is very good. (Teacher of Geography)

I have now learned how to engage my learners with the content, which was very difficult for me before I used these materials. (Teacher of Physics)

Teacher's guide on fieldwork was very useful and this made my life easier. I could handle this topic effectively. (Teacher of Geography)

Case studies are very relevant and useful. I have gained skills on how to involve learners in participating actively in the lessons to create learner-centered-teaching. (Teacher of Entrepreneurship)

Every teacher that has ever gone to teach a class for the first time will agree that it is very intimidating especially if the teacher is not so sure of what to do in terms of planning content, selecting appropriate instructional methods, and assessment strategies for learning. Having exemplar materials to use right at the beginning of the teaching career is a good way to initiate novice teachers into the teaching profession. Indeed, several practicing teachers also reported having gained significant insights from using the ELATE curriculum materials. This is illustrated in the following response:

I have learnt that curriculum materials are more useful when they have practical examples drawing on the day-to-day life of a student. I have learned to use case studies in teaching that it is not to teach only theory but also to help a learner be able to relate to the real life situations. (PT12)

The insights highlighted in the above statement are very important especially in helping learners construct their own knowledge. However, for teachers to be able to use these materials they should perceive and appreciate them as being valuable and relevant to their work.

\section{Perceived Value of the Curriculum Materials}

In order to evaluate the extent to which teachers valued the curriculum materials, they were asked the following question- 
How valuable are the curriculum materials being created and disseminated? - most of the practicing and preservice teachers thought that the curriculum materials were extremely vital in supporting their work. Some of their views on the perceived value of the materials are presented in the following responses:

They were very valuable and useful in terms of encouraging student participation during the lessons. These materials bring abstract learning closer to classroom contexts. (PT16)

The materials reduce the burden of the teacher having to prepare instructional materials since they are already prepared for the teacher to use. These materials are also simplified for all teachers to understand. (PT22)

They are valuable because the curriculum materials give an example of what the teacher should do. When a teacher follows that example it becomes simple for him or her to know what exactly he or she should do. They guide a new teacher on how to plan for a lesson. (PT28)

Recognizing how valuable the materials are in supporting novice teachers, teacher educators have also encouraged their preservice teachers to utilize these OER materials. One teacher trainer concluded that he has "encouraged all the History teacher trainees to access the ELATE website, to enhance the teaching during school practice" (TE1). Another added, "When teaching undergraduate students I refer to these materials as I teach and I spend less time explaining certain concepts than before" (TE5).

If teacher educators orientated their preservice teachers to the materials during their training process, it would become much easier for them to utilize these materials during their school practice. In some of the courses, preservice teachers are required to critique the materials and to give feedback in terms of suggestions for improvement. However, there are some obstacles that could have hindered the use of the ELATE materials in schools.

\section{Obstacles to Proper Utilizations of ELATE Materials in Schools}

In order to understand the obstacles that might be hindering the proper use of the ELATE materials in schools, practicing teachers, authors, and editors were asked "What do you see as the major obstacles to the utilization of the ELATE materials in schools?" In response to this question, most of their concerns rotated around the following: access to computers, Internet connections, fluctuating electric power supply, ICT literacy of teachers and resistance to change. The following response illustrates some of these concerns:

There is relatively poor access to computers and Internet facilities especially in rural schools and yet, most beneficiaries are rural-based. Many of them may not afford the logistics to put in place facilities like computers and electric power. Practicing teachers who are ICT shy don't often change from traditional methods. (TE8)

These are serious challenges that have to be dealt with in order to provide a level ground for all teachers to access OERs particularly those working in rural schools. Rural schools tend to be under privileged in terms of the building infrastructure, access to electricity, access to computers and Internet connectivity, and an adequate supply of qualified teachers.

\section{Suggestions for Improving the ELATE Materials}

After pointing out the challenges that might hinder the proper use of materials, the curriculum authors, editors, practicing teachers and trainees were asked to give their suggestions on how to improve the materials. They gave good feedback presented in this section. Some of the issues raised included (1) an effort to receive feedback from schools, (2) the need to involve key stakeholders, (3) the need to update the materials on a regular basis, (4) an effort to raise public awareness of the available curriculum materials, (5) the need to improve access to computers and Internet connectivity, and (6) turning the e-materials into hard copy print form. Some of these suggestions can be reflected in the following responses:

Make an effort for getting feedback from teachers in schools. The project team needs practical feedback that addresses the obstacles encountered by users of materials in schools. (ED6)

It is essential to involve key stakeholders in curriculum innovation initiatives. Several stakeholders should be brought on board so that the basis on which ELATE was initiated gets a strong foundation. For example, the NCDC should engage ELATE authors in developing more activities to enrich the current national curriculum. More teachers upcountry should also be involved. (PT21)

There is need for continuous and regular updates as users get tired of old materials. The project team needs to consult the latest publications to capture new approaches. Adding more content (topics) will increase on the variety for the teachers 
and other educators. Continuous updates, changing the face photographs and video clips can help too. There is need to continue editing the materials accurately and continually be checking them to remove errors. There is need to add questions from UNEB for years to come, and calling for users to give their opinions on a given website. (ED7)

There is need to disseminate more information about the ELATE materials by sensitizing teachers. Publicization of materials in schools and to the stakeholders in the education system can help improve availability of the materials. It should have wider publicity by the Ministry of Education, universities and District Education Officers. Workshops for teachers should be organized to inform them more about the materials. ELATE brochures should be distributed across Uganda. The media such as televisions can be used to help educate the society about ELATE through education programs. (PT23)

Encourage the use of the wireless connectivity in schools, hold workshops to train teachers on the effective use of the OERs and provide CD ROMs for the schools. (PT20)

Produce booklets or books. The whole syllabus should be worked on. Compiling of the information in their respective subjects in order to print out text books which will be sold from accessible points like bookshops. Some hard copies should be put in major book stores. (PT15)

These suggestions provide a framework that can help as a basis for decision-making on how to improve the usefulness of the materials and their impact on our education sector.

\section{Summary and Discussion of Results}

The results drawn from an ongoing evaluation of the perceptions of the concerned stakeholders involved in the development and use of OERs in the ELATE Programme offers vital insights on how teachers could gain professional growth out of their involvement in the program. The way the ELATE Programme was organized created a favorable environment for teachers and other stakeholders involved acquiring important skills needed to inform their theory and practice. Teachers have gained professional growth and experience through innovative pedagogical skills, action research competencies, communication and writing skills, teamwork, curriculum development and planning. The materials are highly valued by teachers and teacher educators. Subsequently, many teachers and teacher educators are using these materials for teaching. A number of challenges and obstacles hindering the proper utilization of OERs have also been presented, such as poor infrastructure and poor access to computers and Internet connectivity. However, teachers, authors, and editors have provided some important insights on how to improve the ELATE materials. What stands out is the need to seek constant feedback from the users of these materials in order to identify areas for improvement, and also focus on upgrading them on a regular basis so that teachers are encouraged to continue using them. Raising public awareness of the materials also turned out to be very vital. To promote the materials, CD ROMs of revised materials, brochures, and business cards were given out to the participants during the workshops. The ELATE banner was displayed during all the workshops. Given the overwhelming positive reception of the materials, the workshops have been successful in introducing and demonstrating how the materials can be used to the benefit of both the teachers and learners.

The majority of the preservice teachers reported considerable gains and benefits from their interaction with the materials. For instance, many of them indicated that they had found the materials to be teacher friendly and related well to the teachers' and learners' environments. They also commented that the materials saved time that one would have spent looking for other information sources. Teachers also indicated that the materials had very good, brief and interesting introductions to enhance students' engagement and attention. They also found the materials as being helpful because they could be printed out and therefore the preservice teachers did not necessarily need to have access to computers themselves all the time. Most importantly, these materials used locally available resources and provided class activities that enhanced active learning. This increased their potential for better classroom management and use of fieldwork activities. Most of the trainees and some practicing teachers indicated that the examples and the well-designed schemes of work and lesson plans were ideal to their work settings. The Makerere University teacher training program is full time and university-based and school practice comes in at the end. Before school practice, students gained limited insight into the lesson planning process in the real context of the school and had little contact with experienced teachers in the field. Therefore it was difficult to practice the skill of writing schemes of work, lesson plans, and preparing lesson content and student activities with real understanding of how they would be adapted to the resource limitations of schools in the field and how to take advantage of the current practices of experienced teachers.

The ELATE Programme has demonstrated that Africa has great potential to become a major producer of OERs rather than just a consumer of OERs. OERs is the way to go in Sub-Saharan 
Africa in order to meet the demands of teacher education and to improve educational quality (Thakrar, Zinn, and Wolfenden 2009). These materials will offer a huge potential to level the ground between schools, given that these materials are developed by very senior and experienced teachers and subject area experts, such skills could be translated into the materials and therefore can be shared by many more teachers and students. Besides, OERs can be used anywhere, anytime, and by anyone. The OERs uploaded on the project website will help teachers worldwide to learn what goes on in Uganda and Africa in general.

Therefore, a wider group of teachers at Makerere University partner schools, and other schools and teacher training institutions throughout Uganda, will be sharing the good practices exemplified in the ELATE OERs, which have been developed by experienced teachers and subject area experts. This will improve the teaching and learning process at the classroom level and also help create a more level playing field between schools by promoting educational quality throughout the school system in Uganda.

\section{Lessons Learned From the Best Identified Practices}

This program has been very successful in constituting teams of experts to create OERs intended to meet the needs of teachers and students. In the process it has also offered an organizational environment and opportunities for teachers to learn from each other and to become reflective practitioners. Nine of these lessons learned are highlighted below.

First, the notion of utilizing multidisciplinary approaches and multiple perspectives of curriculum authors and editors is a very powerful tool for continuous professional development and needs to be encouraged. Many of our authors and editors have noted that their greatest positive learning experiences happened during the workshops when they were brought together as teachers representing their different subject teams to discuss, share ideas, and give each other feedback.

Second, the active participation of key stakeholders right from the beginning of the program enhanced value congruence for the materials and contributed a great deal to the relevance of the materials to the local needs of teachers and students. In the context of Harland and Kinder's (1997) concept of "value congruence" there is a discussion of the need for sensitivity in achieving an appropriate balance between e-materials of current good practice and perceived best practice. It is not surprising that increasingly, many more people are beginning to appreciate our OERs especially in Uganda and other countries in Africa. This can be demonstrated by the large numbers of visits to the project web portal in the past year totally over 250,000 visits.
Third, the notion of disseminating the materials in the early stages of the program - even when they are still in draft form - is critical because this can allow more targeted people to get oriented to the materials early enough for them so as to offer us constructive feedback. Otherwise however good the materials may be if they are not utilized by potential users early enough it becomes self-defeating in purpose because it often becomes extremely difficult to identify errors in the materials. Thus, our early dissemination and orientation of materials enhanced public awareness of the materials (D'Antoni 2009).

Fourth, in order to speed up the dissemination process and reduce costs, it is important to form synergies with other organizations in terms of aligning dissemination activities such as workshops.

A fifth lesson learned was the need to encourage curriculum authors and editors to participate in the dissemination efforts. These individuals play a vital and valuable role, since they have developed the materials. Since they will have a better understanding of the materials, they can also be extremely helpful in helping to disseminate the materials for wider use.

Sixth, entrepreneurial experts provided a crucial role in advocating to and working with the greater business community. These individuals provided us with much needed information regarding job market demands and needs.

Seventh, the notion of ensuring simplicity and local relevance of the materials is critical. The materials should be user friendly, flexible, and easy to access. Downloadable materials should be in formats that permit users to adopt the materials to their local needs. This program's major contribution was to transform the elearning component of teacher education for new teachers as well as training preservice teachers to transfer their new skills to that of established teachers in their eventual placement schools.

Eighth, the entrepreneurial transferable life skills could be incorporated and taught in any subject content area. Most of our teachers reported much excitement for incorporating and using the materials that could best help their students gain these valuable transferable life skills.

Finally, the team of authors has revised existing materials in the light of feedback provided by stakeholders and subsequently produced new materials to extend syllabus coverage (Ojo and Olakulein 2006). The project team has also created the activities intended to accentuate the contribution of the ELATE Programme to the employability of preservice teachers and of secondary school leavers. This has been done, in part, by extending the entrepreneurship education materials within ELATE and also by promoting the employability of qualified teachers through a national dissemination program to school employers (head teachers and school managers). This has been done by involving 
employers' organizations in the course advisory group so that the new materials are orientated to enhance the employability of students. The enterprise advocates have played a key role in this endeavor.

\section{Conclusion}

The ELATE Programme has a defined product in the form of OERs for teachers; the practice surrounding the use of these materials is embodied in the teacher education program at Makerere University and in the school network. The expertise generated through the project has provided ongoing benefits to the university preservice teachers and practicing teachers in schools. It is intended that renewal and further development of materials and associated research outputs will become embodied in general practice and continue irrespective of the future funding position. Practical involvement of teacher trainers (content experts) in the actual production process of OERs has created self-reliance even when the collaboration has ended.

The project team organized an induction conference and started writing the first of nine units for each of the eight core secondary school subjects. Consequently the ELATE Programme developed OERs enriched with teaching strategies, classroom activities, and teacher guidance across the following eight secondary subjects: Biology, Chemistry, English, Entrepreneurship, Geography, History, Mathematics, and Physics. Drawing on the perceptions of practicing teachers and preservice teachers, this study highlights enormous professional growth through their participation with ELATE OERs. Similarly, the curriculum authors and editors also acknowledged that through their participation in the writing and disseminating processes of the OERs, it has enabled them to fine tune their theoretical underpinnings and practical experience opportunities with teachers in Uganda, Africa, and the world.

\section{References}

D'Antoni, Susan. 2009. "Introduction." In Open Educational Resources Conversations Cyberspace, edited by S. D'Antoni and C. Savage. Paris: UNESCO.

Freiberg, H. Jerome, and Amy Driscoll. 2005. Universal Teaching Strategies. 4th ed. Boston, MA: Pearson Education, Inc.

Good, Thomas L., and Jere E. Brophy. 2003. Looking in Classrooms. 9th ed. Boston, MA: Pearson Education, Inc.

Government of Uganda. 1992. Government White Paper on the Education Policy Review Commission Report Entitled
"Education for National Integration and Development." Kampala: Government of Uganda.

Harland, John, and Kay Kinder. 1997. “Teachers' Continuing Professional Development: Framing a Model of Outcomes." British Journal of In-Service Education 23 (1): 71-84.

Kajubi, Senteza. 1992. The Government White Paper on implementation of the recommendations of the report of education policy review entitled "Education for national integration and development." Kampala: Ministry of Education, Government of Uganda.

Ministry of Education and Sports (MOES). 2005. The Education Sector Annual Performance Report (ESAPR 2005). Kampala: MOES.

MOES. 2008. Head Count List of BTVET Institutions Participating in the UPPET Programme, March 2008. Kampala: MOES.

Moon, Bob, Jenny Leach, and Mary-Priscilla Stevens. 2005. Designing Open and Distance Learning for Teacher Education in Sub-Saharan Africa: A Toolkit for Educators and Planners. Washington, DC: World Bank.

Murphy, Patrick D. 2003. Uganda: Adjustment Operations in Support of Education. London: Henley Publishing. Available online at: http://www.sustdev.org/Features/uganda.html.

Ojo, Olugbenga David, and Felix Kayode Olakulein. 2006. The Place of Multiple Intelligence in Achieving the Objectives and Goals of Open and Distance Learning Institutions: A Critical Analysis. Turkish Online Journal of Distance EducationTOJDE 7 (3): 19-27.

Ornstein, Allan C. 1995. Strategies for Effective Teaching. 2nd ed. Dubuque, IA: Wm. C. Brown Communications, Inc.

Republic of Uganda. (2010). Uganda National Report for the implementation of Programme of Action for the least developed countries for the decade 2001-2010. Kampala: Ministry of Finance, Planning and Economic Development.

Strauss, Anselm C., and Juliet M. Corbin. 1998. Basics of Qualitative Research: Techniques and Procedures for Developing Grounded Theory. 2nd ed. London: Sage Publications.

Thakrar, Jayshree, Denise Zinn, and Freda Wolfenden. 2009. "Harnessing Open Educational Resources to the Challenges of Teacher Education in Sub-Sahara Africa." The International Review of Research in Open and Distance Learning 10 (4): 1-9.

Uganda Bureau of Statistics (UBOS). (2010). Uganda Household Survey Report 2009/10. Kampala: UBOS.

UNESCO. 1994. "World Declaration on Education for All and Framework for Action to Meet Basic Learning Needs." In World Conference on education for all meeting basic learning needs, ed. by Secretariat. 5-6 March 1990. Jomtien, Thailand: UNESCO. 